\title{
Drying Effects on Phytochemicals and Antioxidant Properties of Ginger Powder Undergoing Different Drying Techniques
}

\author{
A. Sarkar, M. Rashid, M. Musarrat, and M. Billah
}

\section{ABSTRACT}

The objective of this study was focused on drying techniques including oven, mechanical, sun and shade drying on changes in phytochemicals and scavenging antioxidant capacity of ginger powder. The dry ginger had highest phenolics content $(487.87 \pm 2.63 \mathrm{mg}$ GAE$/ \mathrm{g})$ and flavonoids $(322.63 \pm 3.74 \mathrm{mg} R E / g)$ on weight basis. The highest DPPH antioxidant scavenging capacity in $(78.13 \pm 1.02 \%)$ and highest FRAP assay in $(38.64 \pm 0.76 \mathrm{mmol} F(\mathrm{II}) / \mathrm{mg})$. Oven drying technique had a positive effect on retaining flavonoids content. Shade drying technique had a positive effect on retaining phenolics content, ascorbic acid and DPPH antioxidant scavenging activity assay. On the other hand, sun drying technique had a positive effect on retaining FRAP antioxidant assay. The changes in antioxidant scavenging activity due to the drying techniques were positively correlated with phytochemicals content.

Drying techniques caused a significant change in phytochemicals and antioxidant activity in dry ginger. However, it can be recommended that special technique should be taken for processing that phytochemicals and antioxidant scavenging capacity remain in processed ginger powder.

Keywords: Antioxidant activity, Drying techniques, Nutritional composition, Phytochemicals.
Published: February 20, 2021

ISSN: $2684-1827$

DOI: $10.24018 /$ ejfood.2021.3.1.236

\section{A. Sarkar}

Biomedical and Toxicological Research Institute (BTRI), BCSIR, Bangladesh.

(e-mail: asarkar109@gmail.com)

M. Rashid*

Institute of Food Science and Technology (IFST), BCSIR, Bangladesh.

(e-mail: Mamunrashid810@gmail.com) M. Musarrat

Institute of Food Science and Technology(IFST), BCSIR, Bangladesh.

(e-mail: maeshafood1991@ gmail.com) M. Billah

Daffodil International University, Department of food and nutrition,

Bangladesh.

(e-mail: masumb01914@gmail.com)

*Corresponding Author

\section{INTRODUCTION}

Ginger (Zingiber Officinale) is herbaceous perennial flowering plant belongs to the Zingiberaceae family. Traditionally it is known as oldest spice and used as folk medicine. This plant is used around the whole world in food as a spice in dried and fresh conditions for enhancing the flavor, spicy and pungency taste to the meal [1]. It is a good source of minerals and vitamins (i.e. $\beta$-carotene, ascorbic acid). This plant used as food masala (i.e. pickles, cookies, marmalade) in confectionery, seasoning and flavoring material in diet, bakery products and alcoholic and nonalcoholic beverage [2]. Fresh ginger is a perishable spice causes of improper postharvest management and changes in chemical reaction during storage time. Postharvest management of ginger is not well developed [3]. But, it is important to explore alternative techniques for processing fresh ginger industrially. Drying is the alternative techniques for producing ginger powder and allows them to use in offseason. Dried powder is a substitute product of fresh ginger and stored for long time holding its freshness. It takes small space and lighter in weight rather than raw ginger. For longer shelf life, the dried powder can be an effective solution for processors to make it as a commercial product. It can also be considered as processed product for ready to use in restaurants and homes [4]. Moreover, dried ginger powder has less prone to microbial contamination [5]. There are different drying techniques including sun drying, microwave drying, vacuum drying, freeze drying etc. [6]. The drying techniques can affect to phytochemicals, flavor and color of processed powder. For this, it is an important factor to maintain optimal temperature and rational heat dosage [7]. For producing ginger powder, low temperature drying techniques can be effective for retaining color, flavor, phytochemicals and nutritional contents.

Therefore, the objective of this study was focused on producing ginger powder using low temperature drying techniques viz. oven, sun, mechanical, and shade drying and their drying effects on phytochemicals, antioxidant assessment and nutritional quality evaluation.

\section{MATERIALS AND METHODS}

This research was conducted in Plant Protein Research Section of Plant Food Division of IFST, BCSIR, Dhaka, Bangladesh.

\section{A. Raw Materials Collection}

Fresh and matured ginger rhizome were collected from local market near BCSIR for experimental study. All chemicals and reagent used in this study collected from alfa 
aesar, UK.

\section{B. Ginger Powder Preparation}

Collected ginger rhizome were washed with running tap water. For improving the shelf life and color, cleaned ginger were blanching and soaking into hot water for 20sec. Then immersed in $0.3 \%$ potassium metabisulphite (KMS) solution for 10 minutes at $25^{\circ} \mathrm{C}$ [8]. Chemically processed ginger were cut into 2-5 $\mathrm{mm}$ slices and dehydrated in 4 drying techniques.

i. Sun drying - Sliced ginger were dehydrated in hot sunlight.

ii. Oven drying - Sliced ginger were dehydrated at $(50 \pm 5)$ ${ }^{\circ} \mathrm{C}$ for 6 hours.

iii. Mechanical drying - Sliced ginger were dehydrated in hot air mechanical dryer.

iv. Shade drying- Sliced ginger were dehydrated in shade maintaining room temperature.

Dehydrated ginger slices were ground using a grinder for making fine powder. Prepared GP was stored at $4{ }^{\circ} \mathrm{C}$ in low dense airtight polyethylene bag for further analysis.

\section{Ginger powder preparation}

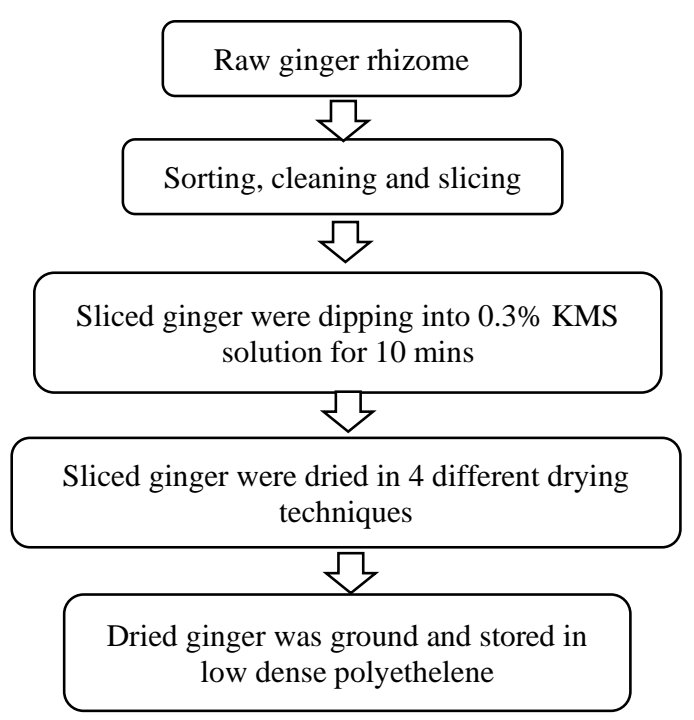

Fig. 1. Ginger powder preparation.

\section{Extraction Techniques}

$10 \mathrm{~g}$ of fresh and dehydrated ginger samples were taken into conical flask and extracted using ethanol (96.6\%) at 1:10 ratio. The sample flasks were shaken at room temperature for 24 hours at $140 \mathrm{rpm}$ using orbital shaker. Then extracts were filtered using whatman filter paper. The ginger residue was then re-extracted by same volume of ethanol for complete extraction. The combined ethanol extracts were concentrated and stored at $4{ }^{\circ} \mathrm{C}$ for further analysis.

\section{Extract Yield $(\%)=[($ Weight of solid extract $\div$ Weight taken for extraction) $\times 100 \%$ ]}

\section{Phenolic Content Estimation}

Phenolic content was determined following FolinCiocalteau method [9].100 $\mu \mathrm{L}$ of aliquots ethanolic extracts were taken and up to the marked with $1 \mathrm{ml}$ ultra-pure water. $2.5 \mathrm{ml} 20 \%(\mathrm{w} / \mathrm{v}) \mathrm{Na}_{2} \mathrm{CO}_{3}$ solution and $0.5 \mathrm{ml}$ FolinCiocalteu reagent was mixed. Then the mixed solution was kept in absence of light for 40 mins at $25{ }^{\circ} \mathrm{C}$. Sample absorbance was taken at $725 \mathrm{~nm}$ with UV-Spectrophotometer and result was estimated as $\mathrm{mg} / \mathrm{g}$ of GAE of dry extract.

\section{E. Flavonoid Content Estimation}

Flavonoid content of ginger extract was estimated following method ensued by Zhishen et al. [10].100 $\mu \mathrm{L}$ ginger extract was marked up to $2 \mathrm{ml}$ with ultra-pure water. $0.15 \mathrm{ml} \mathrm{NaNO} 2$ (5\% solution) was mixed to the solution. This solution was left for 6 mins for incubation. Then $150 \mu \mathrm{l}$ aluminum tricholoride (10\%, solution) was mixed. Then the solution was left for six mins. $2 \mathrm{ml} \mathrm{NaOH}$ (4\%, solution) was mixed to the previous solution and was marked up-to $5 \mathrm{ml}$ with ultra-pure water. After that the solution was vortexed and kept for 15 mins in dark. The resultant color was yellowish-orange and absorbance was taken at $510 \mathrm{~nm}$. Flavonoid content result was calculated as $\mathrm{mg} / \mathrm{g}$ of RE of dry extract.

\section{F. (Ferric Reducing Antioxidant Power) FRAP Assessment}

FRAP assessment of dry sample extracts was estimated following this method [11]. This solution composed of $2.5 \mathrm{ml}$ of $1 \%\left[\mathrm{~K}_{4} \mathrm{Fe}(\mathrm{CN})_{6} .3 \mathrm{H}_{2} \mathrm{O}\right](\mathrm{w} / \mathrm{v})$ and $2.5 \mathrm{ml}$ of $0.2 \mathrm{M}$ phosphate buffer solution (combination of $38 \%$ dibasic \& $62 \%$ monobasic, where $\mathrm{pH} 6.5$ ). Then $1 \mathrm{ml}$ of standard Gallic acid and Ascorbic acid and ginger extracts at 5 successive concentrations $(25,50,100,250$ and $500 \mu \mathrm{g} / \mathrm{ml})$ were mixed to FRAP mixture. That solution was broiled in water bath at $50{ }^{\circ} \mathrm{C}$ for $20 \mathrm{mins}$. After that, 2.5 mililiter $10 \% \mathrm{TCA}(\mathrm{w} / \mathrm{v})$ was added and the solution was centrifuged for $10 \mathrm{mins}$ at $3000 \mathrm{rpm} .0 .5 \mathrm{ml}$ of freshly prepared $0.1 \% \mathrm{FeCl}_{3}$ solution and $2.5 \mathrm{ml}$ ultra-pure water were mixed to the centrifuged transparent solution. Then resultant mixture was kept for 10 mins at $25{ }^{\circ} \mathrm{C}$. Radical inhibition percentage of the ginger extracts was determined at $700 \mathrm{~nm}$ opposing the $\mathrm{CH}_{3} \mathrm{OH}$ blank. Concentration of $\mathrm{FeSO}_{4}$ equal in millimole was estimated from the curve of standard solution and exposed as $\mathrm{mg}$ of $\mathrm{Fe}$ (II) equivalent/mg.

Inhibition $(\%)=[($ Absorbance of sample- Absorbance of control $) \div$ Absorbance of sample] $\times 100$

\section{G. DPPH Radical Scavenging Assessment}

DPPH [2,2-diphenyl-1-(2,4,6- trinitrophenyl) drazyl] free radical scavenging activity of processed dry ginger extract was measured following method ravichandran et al. [12]. $0.1 \mathrm{ml}$ of methanol extract of ginger was added with DPPH solution $\left(6 \times 10^{-5} \mathrm{M}\right)$. After that the solution was broiled for 30 mins at $25{ }^{\circ} \mathrm{C}$. Then sample absorbance was taken spectrophotometrically at $515 \mathrm{~nm}$, where methanol used as positive control and blank. Antioxidant radical scavenging activity was estimated as

DPPH radical-scavenging activity $(\%)=\left[\left(\mathrm{A}_{\text {control }}-\mathrm{A}_{\text {sample }}\right) \div\right.$ $\left.\mathrm{A}_{\text {control }}\right] \times 100$

\section{H. Nutritional Composition}

Nutritional parameter (i.e., ash, moisture, crude fat, protein and crude fiber) of dried GP were estimated following AOAC,2005 procedure [13]. Digestible carbohydrate content was estimated by difference [14]. Ascorbic acid content was 
estimated following 2, 6-dichlorophenol indophenols titration procedure described by Rao and Deshpand [15].

\section{Statistical Analysis}

Statistical data were analyzed using SPSS software, version 22, SPSS Inc. Chicago, Illinois, USA. Data values were exposed as a percentage and mean \pm SD. One-way ANOVA along with Bonferroni post hoc test was used to analyze the significance/non-significance of the mean values between different groups. The findings were considered as statistically significant if $\mathrm{p}<0.05$.

\section{RESULT AND DISCUSSION}

Table 1 represents the yield of dry sample and its flavonoid and phenolic content of dried ginger powder using various drying techniques. The extract yield of dried ginger powder ranged from $5.89 \pm 1.37 \%$ to $7.65 \pm 0.89 \%$, where the highest yield for oven dried ginger powder and lowest yield for shade dried ginger powder. Drying techniques makes the structural cell more fragile and homogenized during milling. For which, fragile cell releases more organic compounds in extract solvent during extraction process [16].

TABLE 1: EXTRACTS YIELD, FLAVONOID CONTENTS AND TOTAL PHENOLIC CONTENT OF DRY GINGER EXTRACTS

\begin{tabular}{cccc}
\hline Dried ginger & Yield (\%) & $\begin{array}{c}\text { TPC, mg } \\
\text { GAE/g }\end{array}$ & FC, mg RE/g \\
\hline Sun drying (SD) & $6.72 \pm 1.21$ & $352.98 \pm 2.67$ & $256.76 \pm 2.43$ \\
Oven drying (OD) & $7.65 \pm 0.89$ & $310.74 \pm 4.78$ & $322.63 \pm 3.74$ \\
$\begin{array}{c}\text { Mechanical } \\
\text { drying (MD) } \\
\text { Shade drying } \\
\text { (SHD) }\end{array}$ & $6.12 \pm 0.86$ & $336.67 \pm 3.32$ & $320.52 \pm 3.56$ \\
\hline
\end{tabular}

Values are Mean $\pm \mathrm{SD}$, Values are sharing in common superscript are significantly different $(\mathrm{P}<0.05)$. Key: $\mathrm{FC}=$ Flavonoid contents, $\mathrm{TPC}=$ Total phenolic content.

The phenolic content of dried ginger powder exposed as $\mathrm{mg}$ GAE/g. Highest amount of phenolic content (487.87 $\pm 2.63 \mathrm{mg} \mathrm{GAE} / \mathrm{g})$ in SHD ginger powder and lowest amount in $(310.74 \pm 4.78 \mathrm{mg} \mathrm{GAE} / \mathrm{g})$ oven dried ginger powder. Sun dried ginger powder samples contained higher amount of phenolic content than mechanical dried ginger powder samples. Temperature might be a factor for phenolic content results variation. Low temperature helps to pertain the phenolic content in ginger powder [17]. For which shade dried ginger powder contained high amount of phenolic content. The flavonoid content result for sun dried, oven dried, mechanical dried, shade dried ginger powder were $256.76 \pm 2.43,322.63 \pm 3.74,320.52 \pm 3.56,221.34 \pm 4.12 \mathrm{mg}$ $\mathrm{RE} / \mathrm{g}$ respectively. Its values were significantly $\mathrm{p}<0.05$ different. Oven dried ginger powder contained highest amount of flavonoid content. Drying temperature was the factor for releasing flavonoid content from the cell structure of homogenized powder. Both flavonoids and phenols are natural polyphenolic compounds and it may depict its effect through anti-oxidative activity and works as singlet oxygen scavengers, working antioxidant enzyme, reducing free radicals and inhibiting oxidases in biological system [18].

The antioxidant assay of dried ginger powder regarding its capacity to scavenge free radicals was assessed. The ROS and producing of free radicals are the crucial factor for inflammation, degenerative diseases and so on. Fig. 1 represents the capacity of dried ginger powder extracts to scavenge DPPH free radicals in ginger powder. The highest FRAP value was noticed in sun dried $(38.64 \pm 0.76 \mathrm{mmol}$ $\mathrm{Fe}(\mathrm{II}) / \mathrm{mg}$ ) in ginger powder and lowest in shade dried $(28.38 \pm 0.46 \mathrm{mmol} \mathrm{Fe}(\mathrm{II}) / \mathrm{mg})$ ginger powder. Mechnical dried $(33.78 \pm 0.78 \mathrm{mmol} \mathrm{Fe}(\mathrm{II}) / \mathrm{mg})$ ginger powder FRAP value were little bit higher than oven dried $(32.89 \pm 0.81 \mathrm{mmol}$ $\mathrm{Fe}(\mathrm{II}) / \mathrm{mg}$ ) ginger powder. DPPH percentage was ranged from shade dried $(78.13 \pm 1.02 \%)$ to sun dried $(62.45 \pm 0.77 \%)$. Mechanical dried ginger powder DPPH value $(65.47 \pm 0.68 \%)$ was little bit higher than oven dried ginger powder DPPH $(62.45 \pm 0.77 \%)$. Sun dried ginger powder contained high amount of FRAP activity, that might be plants experiencing periodic changes and also stress-induced revulsion in presence of sun light [19].

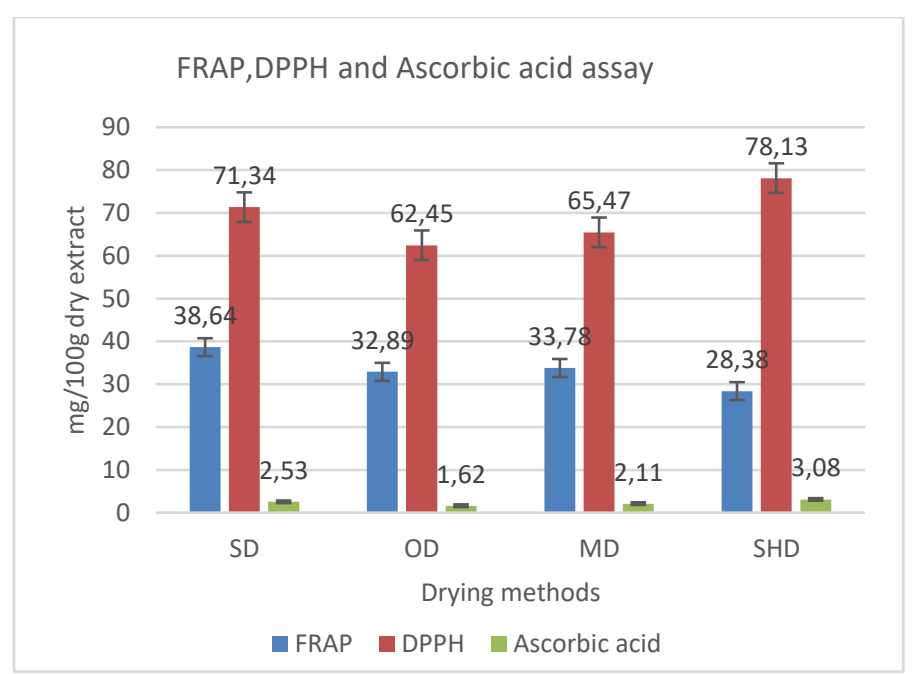

Fig. 2. FRAP, DPPH and Ascorbic acid assessment.

Sun-dried ginger extracts showed high level of antioxidant activity that might be due to plants experiencing developmental changes and stress-induced responses due to sunlight [19]. The moisture content being reduced during drying time and through biochemical processes sunlight the natural radiation stimulates the protective metabolite pathways that effect on phenolic antioxidants. For which sundried ginger powder might increase the potential bioactivity and phytochemical of dry ginger powder [20]. Antioxidants have a crucial impact on food acceptability and safety. It inhibits the oxidation and effective against microbial growth. Dried ginger extracts antioxidant capacity to scavenge DPPH inhibition might be connected to hydrogen donor molecules of polyphenolic nature. That was manifested as good scavenging of DPPH capacity. Ascorbic acid ranged from $1.62 \pm 0.10$ to $3.08 \pm 0.20 \mathrm{mg} / 100 \mathrm{~g}$. It has an antioxidant activity and essential nutrient for human metabolic function. It works as cofactor for different enzymatic reaction and biological function in human body. It is essential for tissue forming, collagen making, iron absorbing and wound healing [21]. 
TABLE 2: PROXIMATE COMPOSITION OF DRY GINGER

\begin{tabular}{ccccc}
\hline Parameters & Sun Dry & Oven dry & $\begin{array}{c}\text { Mechanical } \\
\text { Dry }\end{array}$ & Shade Dry \\
\hline Moisture, \% & $5.13 \pm 0.18$ & $4.22 \pm 0.28$ & $4.74 \pm 0.24$ & $8.10 \pm 0.24$ \\
Ash, \% & $3.17 \pm 0.09$ & $3.41 \pm 0.08$ & $4.01 \pm 0.10$ & $3.10 \pm 0.12$ \\
Acid insoluble & $0.31 \pm 0.11$ & $0.25 \pm 0.14$ & $0.38 \pm 0.09$ & $0.30 \pm 0.15$ \\
ash, \% & $1.20 \pm 0.21$ & $1.08 \pm 0.16$ & $1.15 \pm 0.21$ & $1.35 \pm 0.25$ \\
Fat, \% & $91.70 \pm 0.14$ & $92.37 \pm 0.18$ & $91.25 \pm 0.16$ & $88.80 \pm 0.18$ \\
Organic matter, \% & $6.35 \pm 0.09$ & $6.58 \pm 0.07$ & $6.18 \pm 0.05$ & $6.21 \pm 0.03$ \\
Protein, \% & $4.32 \pm 0.10$ & $3.87 \pm 0.13$ & $5.01 \pm 0.06$ & $4.51 \pm 0.12$ \\
Crude fiber, \% & $79.83 \pm 0.12$ & $80.84 \pm 0.17$ & $78.91 \pm 0.11$ & $76.73 \pm 0.22$ \\
Carbohydrate, \% & &
\end{tabular}

Values are Mean $\pm \mathrm{SD}$, Values are sharing in common superscript are significantly different $(\mathrm{P}<0.05)$.

Proximate composition of dry ginger results represents in Table 2. Moisture content result ranged from $4.22 \pm 0.28$ to $8.10 \pm 0.24 \%$. Mechanical dried ginger powder moisture content $(4.74 \pm 0.24 \%)$ little bit higher than oven dried ginger powder moisture content (4.22 $\pm 0.28 \%$ ). Shade dried ginger contained highest moisture content cause of drying in low temperature than other drying techniques. Moisture content is responsible for microbial contamination. Traditional oven was more effective for removing moisture from processed ginger [22]. However, different drying method showed different moisture percentage and that was an indication of shelf life of processed ginger. Highest ash content in $(4.01 \pm 0.10 \%)$ mechanical dried ginger and lowest ash content in $(3.10 \pm 0.12 \%)$ shade dried ginger powder. Oven dried and sun dried ginger powder ash content were $(3.41 \pm 0.08 \%)$ and $(3.17 \pm 0.09 \%)$ respectively. Ash content indicates the presence of salt content in ginger powder. It is closely related to presence of different types of minerals. Different types of minerals are responsible for human metabolic functions. Sun dried, oven cried, mechanical dried and shade dried ginger powder acid in soluble ash were $0.31 \pm 0.11,0.25 \pm 0.14$, $0.38 \pm 0.09$ and $0.30 \pm 0.15 \%$ respectively. No significant difference $(p<0.05)$ was observed acid insoluble results. Acid insoluble ash indicates the presence of soluble salt. Soluble salt helps to release the indigestion problem of human [23]. Fat content for sun dried, oven dried, mechanical dried and shade dried ginger powder were $1.20 \pm 0.21,1.08 \pm 0.16$, $1.15 \pm 0.21, \quad 1.35 \pm 0.25 \%$ respectively. No significant difference $(\mathrm{p}<0.05)$ was observed in fat content results. It is holding flavoring, organic volatile matter and also responsible for microbial contamination [24]. The organic matter indicates presence of organic substance in stuffs. It ranged from $(88.80 \pm 0.18 \%)$ in shade dried to $(92.37 \pm 0.18 \%)$ oven dried ginger powder. Sun dried ginger organic matter $(91.70 \pm 0.14 \%)$ content was little bit higher than mechanical dried ginger organic matter $(91.25 \pm 0.16 \%)$ content. Naturally organic matter composed of carbon based compounds such as cellulose, lignin, cutin, tannin, saponin and also various types of carbohydrates, proteins and lipids. Organic matter plays an important factor for retention in the water and nutrients in organic cell-wall [25]. The protein content for sun dried, oven dried, mechanical dried and shade dried ginger were $6.35 \pm 0.09,6.58 \pm 0.07,6.18 \pm 0.05$ and $6.21 \pm 0.03 \%$. No significant difference $(\mathrm{p}<0.05)$ was observed in protein content results. Protein content have an impact on rheological property of flour. The higher protein percentage makes the flour chewy and crusty and less protein percentage makes softer. Moreover, it indicates the amount of amino acid content which is important for human metabolic function
[26]. Highest crude fiber content was observed in mechanical dried $(5.01 \pm 0.06 \%)$ and lowest in $(3.87 \pm 0.13 \%)$ oven dried ginger powder. Sun dried and shade dried ginger powder fiber content was $4.32 \pm 0.10 \%$ and $4.51 \pm 0.12 \%$. Fiber content is responsible for digestibility and controlling appetite. Carbohydrate content ranged from $76.73 \pm 0.22$ in shade dried to $80.84 \pm 0.17 \%$ in oven dried ginger powder. Ginger powder contained a good amount carbohydrate content which provides energy to cell [27].

Body needs different types of macronutrients carbohydrate is one of them. In body metabolic reaction carbohydrates convert into glucose and produce energy which is essential for body cell.

\section{CONCLUSION}

From the results, drying processes have an effect on retaining the antioxidant scavenging activity and phytochemicals in dried ginger. The sun drying techniques had significantly higher FRAP value on the other hand shade drying techniques had significantly higher DPPH radical scavenging activity.

So the processing techniques could be an important matter for preserving the phytochemicals and antioxidant. Such assessment is the requirement of consumers causes they are now depended on processed nutraceutical or functional foods.

\section{ACKNOWLEDGEMENT}

Authors are thankful to the Director of Biomedical and Toxicology Research Institute and Institute of Food Science and Technology, BCSIR, Dhaka, Bangladesh for giving permission to conduct this research work.

\section{REFERENCES}

[1] Jayashree E, Visvanathan R (2011) Physical and biochemical parameters of fresh and dry ginger 315 (Zingiber officinale Roscoe). J Spices Aromat Crop 20:14-21.

[2] Plotto A (2002) Ginger: post-production management for improved market access.

[3] Pruthi JS (1993) Major spices of India: crop management and postharvest technology. Indian 331 Council of Agricultural Research.

[4] Ahmed J, Shivhare US (2001) Thermal kinetics of color change, rheology, and storage characteristics of garlic puree/paste. J Food Sci 66:754757https://doi.org/10.1111/j.1365- 2621. 2001.tb04633.

[5] Prasad J, Vijay VK, Tiwari GN, Sorayan VPS (2006) Study on performance evaluation of hybrid drier for turmeric (Curcuma longa L.) drying at village scale. J Food Eng 75:497-502. https://doi.org/10.1016/j.jfoodeng.2005.04.061.

[6] Jayashree E, Visvanathan R, John Zachariah T (2014) Quality of dry ginger (Zingiber officinale) by different drying methods. J Food Sci Technol 51:3190-3198. https://doi.org/10.1007/s13197-012-0823-8.

[7] Figiel, A. (2010). Drying kinetics and quality of beetroots dehydrated by combination of convective and vacuum-microwave methods. Journal of Food Engineering, 98/4, 461-470.

[8] Singh H, Bawa AS, Ahmed J (1997) Dehydration Characteristics of Green Leafy. Indian Food Pack 51:5-13.

[9] Loganayaki, N.; Siddhuraju, P.; Manian, S. Antioxidant activity and free radical scavenging capacity of phenolic extracts from Helicteres isora L. and Ceiba pentandra L. J. Food Sci. Technol. 2013, 50, 687695.

[10] Jayanthi, P., Lalitha, P., 2011. Reducing power of the solvent extracts of Eichhornia crassipes (Mart.) Solms. Int. J. Pharm. Pharmaceut. Sci. 3 (3), 126-128.

[11] Ravichandran K, Saw NMMT, Mohdaly AAA, Gabr AMM, Kastell A, et al. (2013) Impact of processing of red beet on betalain content and antioxidant activity. Food Res Inter 50: 670-675. 
[12] AOAC Official methods of analysis of AOAC international, $18^{\text {th }}$ ed. AOAC international, gaithersburg Md; 2005.

[13] Eneche EH. Biscuit-making potential of millet/pigeon pea flour blends. Plant Foods for Hum Nutr. 1999;54:21-27.

[14] Rao BS, Deshpande V. Experimental Biochemistry. Anshan Ltd.; 2006.

[15] Shirsath, S.R.; Sonawane, S.H.; Gogate, P.R. Intensification of extraction of natural products using ultrasonic irradiations-A review of current status. Chem. Eng. Process. Process Intensif. 2012, 53, 10-23.

[16] Chan, E.W.C.; Lim, Y. Y.; Wong, S.K.; Lim, K.K.; Tan, S.P.; Lianto, F.S.; Yong, M.Y. E_ects of di_erent drying methods on the antioxidant properties of leaves and tea of ginger species. Food Chem. 2009, 113, $166-172$.

[17] Shetty, K.; McCue, P. Phenolic antioxidant biosynthesis in plants for functional food application: Integration of systems biology and biotechnological approaches. Food Biotechnol. 2003, 17, 67-97.

[18] Ling, A.L.M.; Yasir, S.; Matanjun, P.; Abu Bakar, M.F. E_ect of di_erent drying techniques on the phytochemical content and antioxidant activity of Kappaphycus alvarezii. J. Appl. Phycol. 2014, 27, 1717-1723.

[19] Dixon, R.A.; Paiva, N.L. Stress-induced phenylpropanoid metabolism. Plant Cell 1995, 7, 1085-1097.

[20] Dugasani, S.; Pichika, M.R.; Nadarajah, V.D.; Balijepalli, M.K.; Tandra, S.; Korlakunta, J.N. Comparative antioxidant and antiinflammatory e_ects of [6]-gingerol, [8]-gingerol, [10]-gingerol and [6]-shogaol. J. Ethnopharmacol. 2010, 127, 515-520.

[21] Bankole, S.A., Osho, A., Joda, A.O. and Enikuomehin, O.A. 2005. Effect of drying method on the quality and storability of 'egusi' melon seeds (Colocynthis citrullus L.). African Journal of Biotechnology 4(8): 799-803.

[22] Moshafi, M.H., Fariba, S., Dehghan, R.G., Ameri Ali, E.H. 2009.Bioassay screening of the essential oil and various extracts of fruits of Heracleumpersicum Desf. and Rhizomes of Zingiber officinale Rocs. using Brine Shrimp cytotoxicity assay. Iranian Journal of Pharmaceutical Research, 8(1), 59-63.

[23] famurewa, A.V., Emuekele, P.O., Jaiyeoba, K.F. 2011. Effect of drying and size reduction on the chemical and volatile oil contents of ginger (Zingiber officinale). Journal of Medicinal Plants Research, 5(14), 2941-2944.

[24] EI-Ghorab, A.H., Nauman, M., Anjum, F.M., Hussan S., Nadeem, M. 2010. A comparative study on chemical composition and antioxidant activityof Ginger (Zingiber officinale) and cumin (Cumunum cyminum). J. Agric. Food. Chem., 58(14), 8231-8237.

[25] Bradford, M.M., 1976. A rapid and sensitive method for the quantification of microgram quantities of protein utilizing the principle of protein-dye binding. Analytical Biochemistry 72, 248-254.

[26] Onu, L.I. and Okafor, G.I. 2003. Effect of physical and chemical factor variations on the efficiency of mechanical slicing of Nigerian ginger (Zingiber officinale rose). Journal of Food Engineering 56: 43- 47. 